\title{
Monitoring Bean pod mottle virus and Soybean mosaic virus Incidence at Different Soybean Growth Stages in Alabama
}

Edward J. Sikora, ${ }^{\dagger}$ John F. Murphy, and Kassie N. Conner, Department of Entomology and Plant Pathology, Alabama Cooperative Extension System, Auburn University 36849-5624

Accepted for publication 1 June 2017.

Bean pod mottle virus (BPMV) is the most common virus affecting soybean production in the United States, though its impact on yield depends on time of infection relative to plant development, with infection of young plants leading to higher yield reductions (Giesler et al. 2002). BPMV is most readily transmitted during feeding by viruliferous bean leaf beetles (Ceretoma trifucata Foster) (Coleoptera: Chrysomelidae) in the southern United States (Hopkins and Mueller 1984). Soybean mosaic virus (SMV) is found throughout the world wherever soybean is grown, causing yield losses of 8 to 35\% (Hill 2015). Plants infected through seed transmission serve as the primary source of inoculum for the virus, although the soybean aphid, Aphis glycines, and 32 other migratory species can transmit SMV to soybean.

Results from a statewide survey conducted in Alabama showed that BPMV was detected in 58, 65, and $26 \%$ of plants in mature soybean fields in 2008, 2009, and 2010, respectively, with incidence ranging from 2 to $100 \%$ (Sikora et al. 2011). SMV was also found during the survey but reached relatively high levels of infection (48\% of fields) only in 2009, with incidence ranging from 2 to $88 \%$.

This study focuses on BPMV and SMV incidence over time relative to plant growth stage in selected fields located in westcentral Alabama where high levels of both viruses were found previously (Sikora et al. 2011). Five commercial soybean fields, ranging in size from approximately 40 to 200 acres, located within three contiguous counties (Marengo, Pickens, and Sumter) were monitored in 2010 through 2012 and in 2014. All fields were planted with group V soybean varieties which varied by location and year based on grower preferences. Fields were sampled at full bloom (R2), pod fill (R5), and crop maturity (R7), typically in July, August, and September in each year of the study (Fehr et al. 1971). A total of 75 to 125 trifoliate leaves were collected from each field on every sampling date. A trifoliate from the upper canopy was removed from each of five contiguous plants at 15 to 25 locations within a one-acre field section. The central leaflet of each trifoliate was tested individually for BPMV and SMV using a commercial ELISA kit specific to each virus (Agdia Inc., Elkhart, IN). Weekly scouting records from crop consultants for some fields were examined with special attention to bean leaf beetle population densities and feeding damage, and observations of soybean aphids.

Incidence of BPMV was typically highest at R7. BPMV incidence of $10 \%$ or higher was recorded at R2 in at least one field each year of the study. BPMV incidence did not exceed $23 \%$ at R2 in any field except in 2010 when incidence reached $98.7 \%$ at R5 and

${ }^{\dagger}$ Corresponding author. Email: sikorej@auburn.edu

(C) 2017 The American Phytopathological Society
$100 \%$ at R7 in a single field. Even at this high incidence rate, symptoms associated with BPMV were not observed in the field. This was likely due to extended periods of temperatures above $90^{\circ} \mathrm{F}$, which can mask symptoms of BPMV (Hill 2015). Bean leaf beetle populations and feeding damage were typically below economic threshold levels in fields where this information was recorded.

SMV was not detected at high levels during this study and symptoms were not observed. Incidence of SMV above $10 \%$ at R2 was recorded for only one field in 2010. The lack of early SMV infection implies that the disease has limited effects on yield in Alabama. Previous research has shown that yield reduction is negligible when soybean plants are infected after flowering (Irwin and Goodman 1981). Soybean aphids were not observed during this study, indicating that the primary introduction of SMV into Alabama soybean fields may have been through infected seed. Soybean aphids are uncommon in Alabama because the insects' overwintering host, buckthorn (Rhamnus cathartica), is uncommon in the state.

Results from this study, combined with the observations from our previous survey, indicate that BPMV is the most common soybean virus in Alabama. The virus could potentially cause yield loss when bean leaf beetle populations are high early in the season, and infection of soybean prior to flowering is possible. Results also suggest that SMV incidence is low in most years and this virus might not pose a significant threat to soybean production at this time, especially in the absence of high populations of soybean aphids.

\section{Literature Cited}

Fehr, W. R., Caviness, C. E., Burmood, D. T., and Pennington, J. S. 1971. Stage of development descriptions for soybeans, Glycine max (L.) Merrill. Crop Sci. 11:929-931.

Giesler, L. J., Ghabrial, S. A., Hunt, T. E., and Hill, J. H. 2002. Bean pod mottle virus: A threat to U.S. soybean production. Plant Dis. 86:12801289.

Hill, J. H. 2015. Soybean mosaic virus. Pages 114-117 in: Compendium of Soybean Diseases, 5th Ed. G. L. Hartman, J. C. Rupe, E. J. Sikora, L. L. Domier, J. A. Davis, and K. L. Steffey. eds. American Phytopathological Society, St. Paul, MN.

Hopkins, J. D., and Mueller, A. J. 1984. Effect of Bean pod mottle virus on soybean yield. J. Econ. Entomol. 77:943-947.

Irwin, M. E., and Goodman, R. M. 1981. Ecology and control of Soybean mosaic virus. Pages 181-220 in: Plant Diseases and Their Vectors: Ecology and Epidemiology. K. Maramorosch and K. F. Harris, eds. Academic Press, New York.

Sikora, E. J., Murphy, J. F., Lawrence, K. S., and Mullen, J. M. 2011. Survey of fungal, nematode and virus diseases of soybean in Alabama. Plant Health Prog. doi:10.1094/PHP-2011-1227-01-RS 